Драгољуб Ж. Перић Универзитет у Новом Саду Филозофски факултет

Одсек за српску књижевност
УДК 821.163.41-93-32.09 Алексић В. https://doi.org/10.18485/uzdanica.2020.17.1.4

Оригинални научни рад

Примљен: 28. фебруар 2020.

Прихваћен: 1. јун 2020.

\title{
РЕМИТОЛОГИЗАЦИЈА МИТСКЕ ПРОШЛОСТИ - ЛИТЕРАРНА ИНТЕРПРЕТАЦИЈА СЛОВЕНСКОГ ПАНТЕОНА У ЗБИРЦИ ПРИЧА ЗА ДЕЦУ КАЉАВИ КОЊ ВЕСНЕ АЛЕКСИЋ ${ }^{1}$
}

$A \bar{u} c \bar{u} р а \kappa \bar{u}:$ Предмет овог рада представља литерарно моделовање фрагмената словенске митологије у збирци прича Каљави коњ Весне Алексић. С обзиром на то да целовита митска прича о словенским боговима и прворадњама којима они моделују лице света, као демијурзи, не постоји, већ само неколико неповезаних фрагмената, врло штурих историјских података и сведочанстава из времена прихватања хришћанства, као и низ мотива, на нивоу ниже митологије (демонологије), приступ овој грађи изискује посебан опрез јер сваки наредни покушај њене литерарне реконструкције, или пре - трансформације, сусреће се са низом неусаглашености, тамних места, чак и произвољности. Нажалост, Весна Алексић није успела да дорасте таквом изазову: од талентоване списатељице за децу, у овој књизи она се своди на осредњег митотворца који, у покушају да реконструише одређене елементе мита (божанства, њихове атрибуте и функције) у уводним синтезама (причама), тј. дванаест тематских језгара око којих се потом групишу њене кратке приче (често с дететом као наратором или фокализатором), губи наративни ток, уводи нефункционалне ликове и непотребне детаље, само да би приказани свет древне словенске прошлости испао богатији, а митолошко-демонолошки персонални систем (све)обухватнији.

Кључне речи: систем словенске митологије, фолклор, митски прототекст, прича, литерарна трансформација, нарација, секундарни свет, дете - наратор, књижевност за децу.

Систем словенске митологије вероватно је један од најмање познатих и, у научном смислу, најмање целовито истражених. ${ }^{2}$ Прави разлози, по свој

${ }^{1}$ Рад је резултат је истраживања у оквиру пројекта „Аспекти идентитета и њихово обликовање у српској књижевности” бр. 178005, који финансира Министарство просвете, науке и технолошког развоја Републике Србије.

${ }^{2}$ Примера ради, један од најбољих историчара религија, Мирча Елијаде, у свом Воgичу кроз светиске релиїије (1996), после анализа различитих познатих и мање познатих митоло- 
прилици, крију се у томе што аутентични записи и сведочанства о њој из претхришћанских времена не постоје, а први извори у којима се, делимично, осветљава процес христијанизације словенских племена писани су тенденциозно, имена словенских божанстава бележена произвољно или изостављана, или су пак довођена у везу с познатијим митолошким системима - античким грчким и римским - и замењивана познатијим божанствима (међународно преознатљивим).

Па ипак, и овако штури, подаци страних хроничара (Адама Бременског, Титмара, Хелмолда, Сакса Граматика, непознатог састављача Книтлинга саге, три биографије Отона Бамбершког, као и врло суздржане белешке три Византинца: Прокопија, Константина Порфирогенита и Леона Ђакона), као и ретки словенски, указују на то да су Словени, пре примања хришћанства, имали оформљени пантеон, којим су доминирала мушка божанства. ${ }^{3}$ Неретко, ова сведочанства одликује изразито негативан став према „незнабожачким” Словенима, којима приписују (нпр. Херборд) да су „вероломан народ”, који одликује „варварска свирепост” и „незнабожачки фанатизам” (према: Леже 1984: 39). ${ }^{4}$ Ови аутори, и поред све своје уздржаности и фрагментарности сведочанстава о Словенима и њиховој старијој религији, омогућавају да се она, ако не прецизно реконструише, онда барем наслуте њени недостајући елементи. Хелмолд тако, поред мноштва демона природе и божанстава локалног типа, издваја три најзначајнија балтословенска божанства:

[...] u celoj slovenskoj zemlji vlada usrdno klanjanje idolima i zablude raznih sujeverja. Zato su osim gajeva [svetih] i sitnih božanstava, kojih ima u izobilju po poljima i naseljima, prvi i glavni bili Prove, bog Aldenburške [Starogradske] zemlje, Živa, boginja Polabljana, i Radegast, bog zemlje Bodriča. (Рибаков 2015: 398-399, истакао Д. П. $)^{5}$

Словенски извори такође не крију отворени презир хришћанских писаца према незнабошцима. ${ }^{6}$ Они су драгоцени будући да непосредно бележе

шких система, словенској митологији посвећује једва две стране (1996: 267-268), а балтичкој - свега три реченице (1996: 268-269).

${ }^{3}$ О најстаријим изворима о систему словенске митологије в. Леже 1984: 26-42, а понешто се може наћи и у: Ловмјански 1996; Иванов, Топоров 1965; Рибаков 2015; и др.

${ }^{4}$ Ови изразито негативни ставови о Словенима, поред тога што се могу објаснити, с једне стране, типичним предрасудама средњовековних клерика према паганима, могли би имати и дубоко личне разлоге - два Титмарова претка погинула су у борбама са Словенима (Леже 1984: 31), док биографи Отона Бамбершког само потврђују с каквом упорношћу се (привидно) покрштени Словени враћају првобитном паганизму (в. Исто: 36-41).

${ }^{5}$ Укључивши значајан број иначе оскудних извора, Иванов и Топоров реконструишу балтословенски митолошки систем, поменутим трима прикључујући још и следећа божанства: Свентовита, Поревита (Поренута), Подагу, Припегалу, Рујевита, Триглава, Чернобога (Черногловог) и Јаровита (1965: 30-52; 241-242).

${ }^{6}$ Истовремено, из њихових речи незадовољства као да избија некакав пасивни отпор покрштених, који живе „ne slušajući božanske reči, nego ako ih plesači ili svirači ili drugi neki igrači 
прелазак доскорашњих пагана, идолопоклоника, даровалаца старих храмова и приносилаца жртава у хришћанство. Тако, у Несторовој хроници може се наћи податак да, 980. године, кнез Владимир подиже идоле следећим боговима (устоличивши тако тзв. кијевски йаниееон):

I poče da knezuje Vladimir u Kijevu sam. I postavi kumire na brdu izvan dvora sa kulom: drvenoga Peruna sa glavom od srebra i zlatnim brkovima, i Horsa, i Dažboga, i Striboga, i Simargla, i Mokoš.” (Рибаков 2015: 407, истакао Б. Р.) ${ }^{7}$

Овај пантеон кнеза Владимира, креиран из потребе ратничких дружина (Рибаков 2015: 415), уз укључивање Велеса - бога стоке и подземног света, представљао би потпуни митолошки систем Источних Словена (в. Иванов, Топоров 1965: 11-29, 241).

Међутим, предложени реконструисани персонални систем словенске митологије остаје нем када је реч о целовитој митској причи (у смислу античких митова). Он има, с једне стране, хипотетички карактер - племенско поштовање појединих богова мењало се и поједина племена наметала су поштовање својих богова суседним племенима, или су, с друге стране, хришћански владари суседних народа (Финаца, Немаца, Данаца...) приносили словенским боговима дарове, прижељкујући себи успех у предстојећим подухватима (уп. Леже 1984: 78). С друге стране, ови списи представљају сведочанства о тријумфу хришћанства над незнабоштвом, тако да у њима нема места за свете приче о старим боговима новообраћених - ничега више од узгредних осврта на неке од елемената култа и начина поштовања (најче-

pozovu na igrište ili neko zborište idolsko, svi tamo potrče radujući se... i čitav taj dan provedu sramoteći se tamo. [...] Kada te poluhrišćane pozovu na crkvenu službu [...] a oni što ih pozivamo češu se, razvlače, zevaju i kažu: 'Kiša pada...' ili 'Hladno je', sve uzalud radimo! A na sramotištu nema ni krova ni zavetrine, a mnogi dođu i po vetru i po vejavici, i sve radujući se bez pogovora učestvuju u obredu na propast dušama svojim. A u crkvi imaju i krov i zavetrinu, a neće da dođu na službu, mrzi ih." (Рибаков 2015: 377-378)

${ }^{7}$ Примивши хришћанство 988, он наређује да се ови идоли униште, ревносно покрштавајући потом своје поданике и разарајући старе храмове и идоле поменутих богова, као и неких непоменутих (попут Велеса), односно локалних племенских божанстава и демона нижег реда, јавно понижавајући божанства старе религије: „On izda naredbu da se Perun veže konju za rep, i tako dole svuče do ispod Boričeva u potok; za tim naredi dvanaestorici ljudi da ga tuku batinama. Dokle su ga oni tako vukli potokom, nekršteni ljudi nad njim plakahu. Tada, pošto su ga tako dovukli do Dnjepra, bace ga u nj. Vladimir reče svojim slugama: 'Ako se gde zaustavi, odgurnite ga od obale, dok ne prođe vodopad, a tada ga ostavite.' Vetar ga donese do jedne obale, koja se od tada prozva Perunova obala, i koja i danas nosi to ime" (Леже 1984: 59). Сличним јавним понижењима паганских кипова прибегавају и страни мисионари и освајачи, желећи, на тај начин, да укажу на лажну словенску веру. В. опис данског разарања словенског храма у Аркони и рушење Све(н)товидовог идола, дат у Gesta Danorum Сакса Граматика, у коме се врло пажљиво приказује пад идола, при чему „morali su uzeti gvožđe, i čuvati da kip pri padu ne prignjavi koga, jer bi tada neznabošci verovali da se njihov idol sveti”, а притом су његови остаци послужили куварима за ложење ватре (Леже 1984: 79, 80). 
шће - приношење жртве), као и малобројне (и узгред забележене) атрибуте и функције.

Митолошки систем на коме је концептуализована збирка прича Весне Алексић Каљави коњ: йриче из словенске митиолоіије заснива се на дванаесточланом персоналном систему, али не оном балтословенском, чак ни сведенијем источнословенском, већ сопственом (релативно произвољном), при чему сваком божанству одговара један месец реконструисаног словенског календара и њему посвећена уводна синтеза, са пратећом илустративном причом. ${ }^{8}$ Литерарно транспоновани на раван збирке прича оквирног типа чврсте структуре, и добивши по једну целину (месец), наведени богови, штавише, нису увек ни словенски - тако Водан не припада ниједном систему словенске митологије, већ германској митологији (в. Елијаде 1996: 135). ${ }^{9}$ Уосталом, научна тачност није ни била основни циљ ових наратива:

Наука се понекад не слаже с многим подацима који су се усмено пренели до дана данашњег и, богме, лепо сачували. Научници кажу да уметничка обрада старих митова не служи ничему, чак тврде да неки богови, о којима је остало сећање, нису ни постојали. То је научничка ствар. (Алексић 2018: 7)

Ауторку занима усмено предање наших предака - кажа, у коме је сабрана свеукупна мудрост и искуство народа - „све што су знали, од песама, загонетака, пословица, до дивних представа и прича о боговима у које су веровали”, а у њој „читав један разноврсни свет чуда” (Алексић 2018: 6). Тај треперави и привлачни далеки свет прошлости заинтересовао ју је, каже, да трага за њим на интернету и „да прочита[м] неке научне књиге” (Алексић 2018: 7), да би, на крају, дала и библиографију - „Коришћену литературу", ${ }^{10}$ настојећи свом литерарном поступку (заснованом на цитатности, стилистичкој реалистичности и уметничкој трансформацији претежно етнолошких извора и др.) на тај начин да обезбеди уверљивост далеке прошлости

\footnotetext{
${ }^{8}$ Ова аналогија, заправо, више одговара фестивалском календару од дванаест месеци Античке Грчке, заснованом на лунарном циклусу и повезаном са зодијачким кругом.

${ }^{9}$ Као алиби за његово прикључивање, ауторка релативизује његову припадност, а његове функције изводи из народске етимологизације имена: „Нека се не љуте стари германски богови ако за потребе следеће приче 'позајмим' бога Водена из њиховог друштва, али ствари у дубокој прошлости су веома замршене и не можемо баш све доказати. Елем, у сећању народа остало је да бог Воден припада старословенским боговима, а неки научници са јако мрште на то и кажу како је он био германски бог. Било како било, бог Воден је везан за месец децембар и сматра се да је управљао водама.” (Алексић 2018: 95-96)

${ }^{10} \mathrm{O}$ неједнакој научној вредности овде побројане литературе (ауторкиних извора) од псеудонаучне Срйске митиолойије Сретена Петровића, преко нешто убедљивијег $C р \bar{u} с к о \bar{\imath}$ митиолошкой речника, све до сјајних Зечевићевих студија или прворазредне енциклопедије Словенска мийолоїија групе аутора - могло би се посеб́о говорити, али то ће, овом приликом, остати по страни.
} 
- премда не нашег и наших предака (колико год ауторка на томе инсистирала), већ секундарног света (фикције) у правом смислу речи. Кокетујући донекле ca „estetičkim uprizorenjima regresivnih ideologema” (Кравар 2010: 15) fantasy прозе и конвенцијама књижевности за децу (при чему онтогенеза и филогенеза кореспондирају на један особити начин - посредством мита), ${ }^{11}$ Весна Алексић ствара формално (календарски), наративно (често посредством субјективног наратора, односно фокализатора - детета), а ређе мотивски и посредством ликова, повезани низ прича - цртица, које припадају „детињству света" (Алексић 2018: 5).

Вредност ове литерарне трансформације (или, сасвим условно речено, ремитологизације) древне словенске прошлости састоји се у томе што она успешно одолева замкама „ideološki konformne, umjetnički osrednje, ali tržišno probitačne kulturne robe, uglavnom u liku lakše best-selling književnosti” (Кравар 2010: 12), којима, нажалост, припадају бројни српски фантастичари који стварају на почетку новога миленијума, а који кокетују са словенском митологијом, а националне епске јунаке, рутински, убацују у тривијализоване фабуле својих секундарних светова (обавезно скицираних мапама), миметички потпуно остајући у сенци познатијих фантастичара - Џ. Р. Р. Толкина (у бољем случају) или йалй фенйезија Р. Е. Хауарда (познатог по лику Конана Варварина). ${ }^{12}$

Иако не увек на истој висини (а понекад не „добацујући” даље од парафразирања извора и препричавања усменог предања - најчешће етиолошког, $\mathrm{a}$, peђе, на успелијим деоницама - његове поетизације) и немајући снаге ни визије (а можда ни жеље) за призоре великих и судбоносних битака, ауторка посебну снагу своје уметничке имагинације показује - управо у малим, „интимним" причама - о тежњама, спознајама, љубавима... својих ликова, често сасвим посредно повезаних са „великом” („божанском”) причом - уводном синтезом.

Довољно илустративна у овом погледу је приповетка „Каљави коњ” (према којој је збирка и насловљена), заједно са пратећом „Причом о богу Световиду (јуни)". Приповетка говори о рођењу два брата близанца (при чему им суђаје предодређују - једном судбину великог ратника, а другоме - позив жреца), о њиховом одрастању и поновном сусрету, после пет година, непосредно пред „велики рат” (Алексић 2018: 31-38). Њу антиципира „Прича о богу Световиду", где је најпре реч о прорицању судбине новорођенчета

${ }^{11}$ „У време када овај народ почиње да расте, а народи расту као и деца, и свет им се развија налик дечјем, е, ту словенска кажа има велику улогу. Сви тадашњи европски народи имали су своје детињство и све истине овог света доживљавали и откривали кроз мит. Један од историчара записао је да се појава мита поклапа са детињством човечанства и да је мит несавршени израз људског духа који мисли.” (Алексић 2018: 6)

${ }^{12}$ Ненад Гајић са својом Бајком наg бајкама или Милош Петковић са трилогијом Перунов хроничар били би типични представници овога тока. 
и суђајама, потом о їосйоgарчићима (словенским кућним духовима), а тек на крају - о Световиду. Притом, ова уводна прича представља тек незнатну парафразу једног од извора које ауторка помиње - речника Словенска мийолоїија (2001). Основне информације о овом богу у потпуности се подударају - поменут је као:

[...] један од најважнијих богова, а по неким предањима сматран је и врховним богом! У сваком случају, он је био бог рата и победе. Култни центар овог бога, храм на четири стуба, налазио се у балтско-словенском граду Аркони. Сматрало се да бог Световид има четири главе и оне су стајале у вези са четири стране света [...] Уочи рата и при гатању, пророчког коња су наводили на три реда копаља: ако би се спотакао на леву ногу, то се сматрало лошим предзнаком, ако би крочио десном ногом - добрим. (Алексић 2018: 30)

Ово место представља тек незнатну модификацију изворног енциклопедијског текста:

Свентовит - у западнословенској митологији „бог богова”, [...] врховни $\delta о \bar{\imath}$, повезан с ратом и победама [...] Кулйни ценйар С. био је храм на четиири

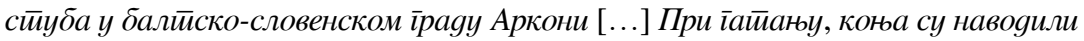

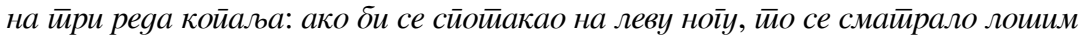
ирреgзнаком, ако би крочио десном ноїом - gобрим. (СМ 2001: 485 - подударања истакао курзивом Д. П.)

Литерарна имагинација ауторке овде, нажалост, није дорасла томе да уметнички трансформише изворе. ${ }^{13}$ Четвороделни модел света (оличен у четири главе божанства које су „стајале у вези са четири стране света” - Алек-

\footnotetext{
${ }^{13}$ Детаљнији, уметнички функционалнији, чак и упечатљивији могући прототекст могао би се наћи у неким другим изворима, нпр. у опису Свентовитовог храма Титмара и Сакса Граматика, непосредно пред његово разарање 1168, који, као свештена лица, а вероватно и очевици, фасцинирани монументалношћу храма и споменика, исписују следеће редове: „u sred grada bejaše jedno mesto, na kome se uzdizaše jedan vrlo lep drveni hram, poštovan ne samo po veličanstvenosti njegovoga kultusa, nego i po idolu koji u sebi skrivaše. Spoljašnjost ovoga hrama bila je ukrašena divnim grubo obojenim drvorezom (accurato celamine) koji predstavlja razne predmete. [...] Oko samoga hrama bejaše dvostruka ograda: spoljna je ograda bila pokrivena crvenim krovom, unutrašnja je sastavljena iz zastora, koji drže četiri koca, a sa spoljnom ogradom dodirivaše se samo krovom. U zgradi bejaše grdan idol, mnogo veći nego u prirodi; imađaše četiri vrata i četiri glave $[\ldots]$ u desnoj ruci držaše jedan rog spravljen od raznih metala; svake godine ga sveštenik puni vinom (mero); i po stanju ovoga pića, on predskazivaše žetvu te godine. Leva ruka drži jedan luk spušten niz telo. Jedna mantija pokriva idolovo telo i spušta se do nogu. Idol bejaše sagrađen od raznih drveta i tako vešto spojenih, da se sastavak mogaše primetiti tek posle najpažljivijeg ispitivanja” (Леже 1984: 75). Иако постоје неке подрударности с овим описом (кров храма у Аркони „има боју прве булке што плане у житу” (Алексић 2018: 34), а у идолов рог у причи „сваке године, после жетве, наливало се вино [...] и по висини течности у њему предвиђала се будућа жетва, пошто је Световид био и бог плодности" [sic] (Алексић 2018: 30)), оне би се дале објаснити даљим преузимањем података из ових извора - из друге (или треће) руке.
} 
сић 2018: 30) подржан је присуством „четири господарчића који, нимало случајно, носе имена страна света" (Алексић 2018: 30), а чија уметничка функционалност у контексту ове и наредне приповетке није најјаснија. Приповетка по којој је збирка и добила име („Каљави коњ”) завршава претварањем Световидовог каљавог коња у крилатог коња, те његовим узлетом на небо (што не види нико сем младога жреца, Сјаја - уп. Алексић 2018: 38), сусретом браће и загрљајем.

Као и у миту, и у овим причама сфера људског и сфера божанског непрестано се додирују, преплићу и међусобно утичу једна на другу. Недостајуће мозаичке фрагменте Весна Алексић ре-креира тако што њена митотворачка имагинација кореспондира са постојећим фрагментима мита (расутим по оскудним изворима и петрифицираним у одређеним фолклорним делима) и доима се као једна алтернативна верзија мита. ${ }^{14}$ Она допричава (недостајући) мит о постанку човека у приповеци „Небески ковач” на следећи начин:

И приђе Сварог храсту и од храста начини биће као што је и сам био. Високо, мишићаво, брадато и дугокосо.

- Ово ће бити први мушкарац на Земљи - рече и окрете се према оближњој липи, па нареди устрепталој супрузи:

- А ти од липе створи прву жену...

Она приђе липи и од ње створи створење слично себи. Меко, нежно, дугокосо и лепо.

- Ово ће бити прва жена на Земљи - задовољно објави.

- А сада јој дај дах и душу - рече Сварог и снажно дуну у мушкарца.

То учини и богиња.

Храст одмах искорачи, а липа затрепта.

И тако настадоше први мушкарац и жена на Земљи. (Алексић 2018: 112)

In illo tempore, Сварог ствара небо, Сунце и Земљу. Напослетку, као што је његова божанска супруга сањала, он ствара и бића налик њима самима, која ће разбити тишину новостворенога света - људе, оставивши им у наслеђе институцију брака (симболизовану прстеном), ватру и писмена - којима ће чувати своје приче. На тај начин, прича о почетку света, почетку годишњег циклуса - јануару (коложегу) и Сварогу (,праоцу или деди свих словенских богова, створитељу рода у целини, извору живота на земљи и дариваоцу свега" - Алексић 2018: 106) прераста у причу о причи:

Како се, иначе, могу сачувати приче да трају дуго, дуго, често се питала млада вила Агниа, гледајући како на Земљи, чак и у вилин-свету, све има свој почетак и свој крај, и изложено је времену као лишће јесењем ветру... (Алексић 2018: 109)

${ }^{14}$ Штавише, читајући ове приче стиче се утисак да постојећи реликти мита, сачувани у ретким средњовековним изворима, жанровима вербалног фолклора и народним обичајима и обредима, на ауторку делују рестриктивно и спутавајуће, више неголи када њих нема. 
Од сведока, мала вила (фокализатор) постаје и учесник збивања, претвара се у лептира, полеће за голубовима пут дуге (финалног украса новоствореног света) да би „кад их је сустигла, намах се опет преобратила у вилу и наставила тако да лети кроз своју причу. До дана данашњег” (Алексић 2018: 117). На тај начин, прича мале виле - сведочење о стварању света, постаје уједно и праприча, извор и узор свих осталих. У ауторској имагинацији Весне Алексић свака прича тако има нечег вилинског у себи - постајући глас који разбија тишину, али и сведочанство о причи и причању.

Наравно, намера ауторке није да научно коректно реконструише словенски митолошки систем, већ да створи један секундарни свет, по узору на постојећи модел који фундира тартуско-московска семиотичка школа (в. Иванов, Топоров 1965; Иванов, Топоров 1974), али не и сасвим подударан са њим. Уз поменуто укључивање богова германске митологије („Прича о богу Водену”), значајнија одступања уочавају се и у извесним неусаглашеностима унутар збирке: врховни бог Старих Словена код ауторке је једног момента Световид, на другом месту - Сварог, а на трећем - Перун, који „господари целим светом" (Алексић 2018: 50). ${ }^{15}$ Заправо, реч је о мешању два митолошка система - источнословенског (у коме господари Перун) и балтословенског (са Свентовитом као врховним божанством), док је Сварог из збирке В. Алексић праотац богова (в. 2018: 106), а у науци реконструисаном митолошком систему - (само) отац Дажбогов!

Перун, као најважније божанство Источних Словена, врховни бог и

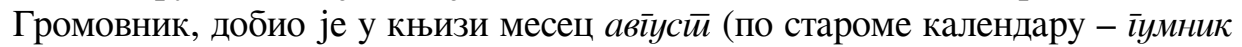
и зарев - в. Алексић 2018: 51-52). У уводној синтези, он је приказан као бог неба, заштитник Сунца, чувар светлости, космичког поретка и задате речи. ${ }^{16}$

\footnotetext{
${ }^{15}$ Увиђајући и сама ове недоследности, она, помињући Перуна као врховног бога, саму себе исправља: „пардон, једног од врховних богова [...] јер наши су преци имали више главних богова, ако ћемо већ да ситничаримо” (Алексић 2018: 52). Без намере да се буде ситничав, може се само приметити да заједнице не функционишу тако да имају „више главних богова”, него реч је о томе да је један бог обожаван у појединој породици народа, групи или племену као главни (нпр. Свентовит у балтословенској или код Западних Словена, а Перун - првенствено међу Источним Словенима), а неки други у другој (без обзира на то колико оне биле блиске, просторно или генеалошки). Или, како Леже примећује, док је „Perun bio veliki bog kijevske i novgorodske Rusije, Svetovid je bio veliki bog Slovena na ostrvu Rujnu” (1984: 73).

${ }^{16}$ „Отуд обичај да су људи, када су посебно желели да им се верује (приликом склапања неког посла или уговора који је ишао на реч), говорили: 'Тако ми Перуна, бога мог!' С том заклетвом нису смели да лажу!” (Алексић 2018: 51). Занимљив податак налази се у Несторовој хроници. Кнез Игор 945. заклиње свој народ - хришћане Богом, а нехришћане - Перуном, над својим мачевима, речима: „Ako neki vladalac (knez) ili neko od naroda ruskog povredi ovo što je ovde napisano, da pogine od svoga oružja, da bude proklet od Boga i od Peruna kao verolomnik" (Леже 1984: 58). Године 971. Светослав свој уговор с Грцима потврђује речима: „Ako ne uščuvamo ovo što smo gore izjavili, neka smo prokleti od bogova u koje verujemo, od Peruna i Volosa, boga stada" (Леже 1984: 59), а постоје забележени и други слични примери заклињања Перуновим именом.
} 
Од атрибута приписује му се храстово дрво, гром и жива ватра. Многоликост атрубута овог божанства представљена је мултиплицирањем потенцијалних наратора, при чему седмогодишњи дечак постаје слушалац и даљи преносилац приче:

То што би нам ратник показао била би ватра у центру насељеног места која се није гасила. То што би нам вила испричала била би прича о његовом знамењу, о верној Брзолетици, коју је по народном веровању Перун уловио у Галицији и коју је, због необичне брзине, припитомио и претворио у свог највернијег друга. ${ }^{17}$ То што би нам, пак, жена показала, био би модри цвет перунике, који је још називан и божјом ружом или божјом биљком.

А о чему би нам причао дечак, откриће вам следећа прича настала на основу старог сачуваног мита.

Даље, у причи која следи („Ала сипа жар на Перуна”), ауторка користи технику сказа како би дочарала уверљивост усменог преношења и приповеда причу о Перуновом сукобу с космичком алом која покушава да прождере Сунце, коју прича сеоски жрец Арнија, а слуша је дечак Плам. Међутим, централна митологема старе словенске религије, везана за Перунов култ, односи се на борбу Бога Грома са змајем (Велесом):

„Перун [...] својим оружјем успева да порази змајоликог непријатеља (у првобитној варијанти мита, то је митолошко биће, коме одговара Волос/Велес, а у познијим текстовима - бајословни Змиулан и сл.), који се од њега скрива, редом, у дрво, камен, човека, животиње, воду. У даљим трансформацијама овог мита може се мењати име (али не и облик) П[еруна] и његовог противника, но основна сижејна схема остаје неизмењена. После победе П[еруна] над непријатељем, ослобађају се воде [...] и излива се киша.” (СМ 2001: 422) ${ }^{18}$

Поставља се, стога, питање зашто је ауторка (која је, као што је претходно показано, читаве пасаже преузимала из овог извора) на овом месту тако драстично одступила - не само од предлошка, већ од читаве (источно)словенске митолошке традиције. У њеној причи се „из дубоког космичког бездана покренула страшна недремива ала. Запловила је према нашем Сунцу кроз космичку невиделицу, разгрћући пред собом звезде” (Алексић 2018: 58). Њен опис упечатљивији је од митског архитекста: „Јахала је на црном двоглавом коњу, бичујући га и терајући дугим пламеним жарачем и ужареним узенги-

${ }^{17}$ Литераризација прототекста и креативна трансформација оскудне грађе могу се пратити и на мотивском нивоу - поменуту брзолетиицу (Перуновог противника из усмене приче, а коју убија неки властелин, оглушивши се о свето време празника и пошавши у лов у недељу, за време службе - уп. Леже 1984: 65-66) ауторка у причи припитомљује и претвара је у захвалну животињу - Перуновог савезника и гласника, који га упозорава на опасност.

18 За више информација о реликтима сижеа о борби Бога Грома и његовог противника (змаја) в. Иванов, Топоров 1974: 75-103. 
јама. Од урлика и церекања њеног одзвањало је небеско гумно смрад се тешки ширио куд год је прошла" (Исто). Измештен у васељенске оквире, он добија космогонијски значај (наликујући више на неке далеке митологије, попут сумерско-акадске, о сукобу бога Мардука и змијолике Тијамат, неголи на словенску). Интенционално, она одустаје и у нарацији од словенског митског сижеа - Перуна, уснулог после испијања медовине, буди Брзолетица, а он се, не часећи, супротставља:

Урликнувши силно, Перун се устреми на алу. Она се окрете, испусти Сунце из чељусти и поче да сипа врели жар на њега. Тада поскочише виле бродарице и виле облакиње, пренуше се ветрови и забрундаше, усталаса се силна вода. Све се поново покрете и оживе. Узаври земља и склопи се небо над њом. Поче страшна битка. (Алексић 2018: 60)

Најпре, овим изменама динамизован је читав опис борбе. Потом, сцену битке обогатила је детаљима пореклом из хронолошки старије традиције индоевропске (змија преобраћена у смртоносно копље). ${ }^{19}$ Такође, значајно је измењен и крај:

[...] Он је нанишанио својим копљем алу у главу. Кад га је хитнуо, копље се намах претворило у страшну змију из чијих уста је севнуо гром и ударио алу у разјапљену чељуст. Од блеска и праска, њен се двоглави коњ поплаши и, њиштећи, пропе.

Највећи храст на земљи прими ту задњу муњу и кроз своје стабло спроведе је у непрегледне дубине, па постаде Свети храст.

Ала пропаде у таму, а виле потрчаше ка рањеном Сунцу да му видају ране.

У истом трену небо поче да се рашчишћава, а Перуну отада припаде и Сунце на чување. (Алексић 2018: 60-61)

Одговор на питање везано за значајнија одступања од мита требало би потражити у природи ових измена. Најпре, из делокруга противника потиснут је митски змај и замењен је алом, а прича завршава призором ведрог неба, уместо кишом која пада (мит). Међутим, змај се појављује у другој причи („Звездана вода”), и то искључиво са позитивном семантиком (за разлику од негативне, или првенствено амбивалентне, какву носи у словенском фолклору). ${ }^{20}$ На тај начин ауторка успева да добије непротивречни лик змаја, активирајући само његов позитиван семантички потенцијал, а негативну уло-

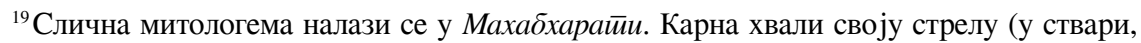
отровну змију, претворену у стрелу) као убојито оружје које може погубити сваког непријатеља: „Ja imam, Salja, ovu krvožednu strelu oštrih čeljusti koja, lepokrila, stoji sama u svom tobolcu [...] Ima zmijsku narav i obličje, otrovna je i žestoka, i može pobiti mnoštvo ljudi, konja i slonova, a probija i oklope i kosti!" (2005: 382).

${ }^{20} \mathrm{O}$ комплексној симболици змаја може се детаљније прочитати у изврсној монографији Милене Беновске-Събкове, Змеят в бългрския фолклор (1992), као и у делу студије о животињама у словенском фолклору, посвећеној змији, тј. змају Александра Гуре (2005: 205-266). 
гу (тј. мрачну, женску, хтонску, деструктивну хипостазу), у својој дуалистичкој концепцији, додељује али.

О змају ауторка детаљније пише у уводној целини, посвећеној јулу (месец жетвар) и богињи Лади следеће:

[...] иако се сматрало да је сваки змај настао од змије коју људско око није видело девет година, змај је позитивни лик у словенском предању. Задатак му је био да чува усеве и сваки берићет од непогода које су изазивале але. Између змаја и ала владао је космички принцип добра и зла. Але су зазивале непогоде и пропасти летина, некад су уништавале и куће и људе, а змајеви су ратовали против њих. (Алексић 2018: 40)

Традиционални круг представа о змају као великом љубавнику ауторка елаборира у наставку, пишући о моћним биљкама, захваљујући којима се жена могла ослободити нежељене пажње змаја:

Дешавало се да се змај заљуби у обичну жену и да почне да јој ствара неприлике, јер га није занимало да ли је она слободна или заљубљена у другог. Змајеви су замишљали да им нико не може одолети, а били су стварно симпатични, снажни и позитивни, како смо то већ видели. Пошто је љубав нешто сасвим лично, и змај је некад морао добити корпу. Е, па да би се решила неког досадног змајевитог удварача, лепа девојка би само ставила поред ува струк босиљка или мелисе (лимунике) и овај би морао да одустане, јер је од тог миомириса добијао неку врсту јаке алергије. (Алексић 2018: 40-41) ${ }^{21}$

У приповеци „Звездана вода” мала Мелиса, „ни вила, ни девојка, ни облак, ни дуга, већ све то заједно...” (Алексић 2018: 42), трага за богињом Ладом. Од змаја (алергичног на лимун-траву, босиљак и гороцвет) добија одговор да је Лада „у плодној киши којом дарује усеве” (Исто: 44); од Месеца сазнаје да је Лада „у мирису лета” (Исто: 42); од учесница краљичке поворке - да је Лада „ипак, само у песми” (Исто: 43); од девојке која гатајући настоји да сазна хоће ли бити срећна у браку - да је Лада „у љубави” (Исто: 44); Лахор јој каже да је Лада „у житу” (Исто: 46); виле је препознају - „у песми птица” (Исто: 47); од патуљака сазнаје Ладу треба тражити „на граници људских веровања” (Исто: 48). ${ }^{22}$ Коначно, у цвркуту јутарње свевидеће птице

${ }^{21}$ Ове биљке и у јужнословенској традицији функционишу као моћни апотропајони против змаја - уп. СМ 2001: 209-210.

${ }^{22}$ Ауторка држи да је место ове богиње спорно у словенском пантеону, поредећи је са изгубљеним фолдером: „Јер реч је о веома тајанственој богињи код Старих Словена, за коју наука данас изричито тврди да није била богиња и да је нема у ионако не увек веродостојној скупини словенских богова. Једноставније речено, сасвим је проблематично њено постојање на старословенском Олимпу" (Алексић 2018: 39). Па ипак, и поред непостојања старијих рукописа (из раног средњег века) у којима би се помињало њено име (што је послужило као основ сумње у њено постојање), то да би је ипак требало прикључити „старословенском Олимпу" потврђују најпре археолошки налази њеног култног места (IX и X век), као и општа 
неће добити никакав одређени одговор, али тек ту доћи ће до ултимативног сазнања - да одговор треба да потражи у себи самој - у своме срцу (Исто: 48). У овој својеврсној природној религији пантеистичког типа, повезујући одговоре својих саговорника који су Ладу налазили у ономе што највише воле, у биљку преобраћена Мелиса коначно прихвата себе и притом открива виши смисао - да је Лада у свему драгоценом, лепом и узвишеном:

Желела сам да упознам богињу Ладу и објаснили су ми да се она налази у свему оном што ја познајем док живим. И што волим. А волим највише да будем оно што јесам: мала мирисна биљка заљубљених, па нека они и нису богови! (Исто: 49)

И тако, исписујући своје Мейаморфозе - тј. креирајући своје поетизовано етиолошко предање о постанку ове биљке, Весна Алексић упућује читаоца да одговоре о суштински битним, животним питањима - тражи у себи самом.

Ова необична збирка (пре цртица обједињених заједничком тематиком, него приповедака у строгом књижевнотеоријском смислу речи), сачињена од микронаративних јединица распоређених у дванаест већих целина (према дванаест месеци, ${ }^{23}$ дванаест издвојених божанстава, дванаест знакова зодијака) и неједнаких естетских домета, ${ }^{24}$ нигде изричито не имплицира

заступљеност њеног имена у фолклору свих словенских народа (Рибаков 2015: 426). Такође, „istorijski i istorijsko-etnografski materijal XV-XVII veka koji imamo na raspolaganju opisuje Ladu kao boginju braka i blagostanja, u čiju čast su održavane svečanosti s proleća (1. maja) i u prvoj polovini leta (Zeleni svjatki u periodu od sredine maja do sredine juna). Sa time se u potpunosti slažu i pesme koje su iz XVIII i prve polovine XIX veka koje su zabeležili etnografi, a u kojima se Lada naziva majkom, svetim božanstvom ili se izjednačava sa bogom tokom prolećnih molitvi za kišu i dobar rod. Niz direktnih obraćanja ('slušaj nas, Lado'; 'pesme, Lado, tebi pevamo'; 'blagoslovi, majko Lado') bez sumnje dokazuje da u očima seljanki koje su pevale pesme reč 'Lado' nije bila besmisleni refren, nego obraćanje jasno personifikovanom božanstvu" (Рибаков 2015: 431).

${ }^{23}$ Месеци у насловима целина именовани су према стандардним називима, док су у самом тексту замењени архаичнијим називима из народног месецослова или су одређени према

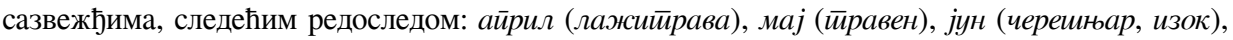

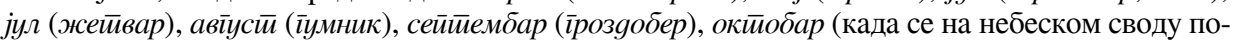
јављују Влашићи, који „својом појавом отварају врата лета и онемогућавају владавину зиме” - в. Алексић 2018: 74), новембар (ірруяен), децембар (са „сазвежђем Китовраса које одговара

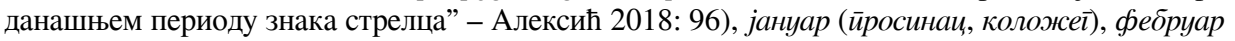
(сечен) и марӣ (gерикожа). Више о народном месецослову у: Недељковић 1990: XIX-XXX.

${ }^{24}$ За разлику од претходних збирки прича „с јасно конституисаним сижеом” (Љуштановић 2012: 142), Каљави коњ делује, у наративном погледу, недовршено (истоимена прича најбољи је пример за то). То, донекле, оправдавају одабрани жанр и, можда, приповедна техника: „тежња ка сажимању карактеристична за кратку причу приморава приповедачки глас да казује само најбитније у ланцу догађаја и да реконструише само најупечатљивије слике, да економише информацијама, да монтира збивање по логици властитих емотивних потреба и да тако остварује приповедачку динамичност, која се огледа у лаким и брзим скоковима у простору и времену" (Исто). И док посебну снагу и естетску оствареност досежу оне приче које говоре о дечјим интимним драмама и спознајама (показујући да и деца из древне прошлости, 
дете као подразумеваног читаоца. Ипак, начином обраћања (типичним за комуникацију старијег с дететом), потом елементима колоквијалног говора, те специфичним одабиром наратора, јунака и фокализатора (првенствено деце: како вилинске, тако и људске), алузијама на њима доступне медије (компјутер, интернет), цртане јунаке и секундарне светове дечје маскултуре (Астерикс и Обеликс - Алексић 2018: 41), она довољно јасно назначава да је имплицирани читалац, пре свега - дете. ${ }^{25}$

Притом, тематизујући искуство одрастања, посредством спознаја својих малих јунака и јунакиња, ауторка открива универзалне истине, скопчане с одрастањем и упознавањем живота: да је сваки посао једнаковредан - и пекарски као и ратнички („Чобанин звезда”), да само трајна радозналост и неутажива жеља за даљинама и за откривањем непознатог омогућавају човеку да досегне звезде („Звезда Клас”), да прича и чежња једине не старе („Вода заборава”). Рефлектујући из перспективе детета смисао среће, човек, за казну због грамзивости претворен у медведа, тек при сусрету са девојчицом која брижљиво чува своје мало благо (квочку и шест пилића) схвата, но прекасно („То је, значи, богатство. Благо. То што је гледао. Та мала, нејака дружина” Алексић 2018: 82), да је за срећу потребно тако мало („Влашићи”).

Укупно узев, ауторка ове збирке (кратких) прича из словенске старине показује истанчани осећај за разумевање интимног живота детета, изазове одрастања и освајања свога места у свету и сопственог идентитета. Па ипак, у покушају да тај идентитет укорени у древној прошлости, она постаје осредњи фентеиези писац или пре - невешти митотворац који, мозаички сачуваним и у различитим изворима петрифицираним фрагментима мита покушава да приступи као и свакој другој грађи, распоређујући је у неке необичне (а неретко чудне или произвољне) констелације.

\section{ИЗВОРИ}

Алексић (2018): Весна Алексић, Каљави коњ, Чачак: Пчелица издаваштво.

Махабххарата (2005): Mahabharata, Zamislili, izabrali i preveli s engleskog Slobodan Vlaisavljević i Goran Andrijašević; sa sanskrtskim izvornikom uporedio, izradio

баш као и ова данашња, деле исто, универзално искуство одрастања, скопчано са откривањем живота, самодоказивањем и превазилажењем сопствених страхова), оне приче које се конституишу као предмет њихове фасцинације - (мистификовани или у изворима засведочени) фрагменти мита о борбама богова или приче о сусрету човека с различитим представницима света демонологије - делују (нажалост) бледуњаво и неубедљиво.

${ }^{25}$ У погледу наративног поступка, ова збирка не представља већи помак у односу на њене претходне збирке. Штавише, исти је одабир наратора и модуса приповедања. Као што је већ примећено за раније збирке, ,већину прича Весне Алексић причају деца [...] позиција одраслог дата је по правилу спорадично и фрагментарно - важније је пређашње Ја детета од одраслог који носталгично путује у прошлост. Деца - приповедачи [...] и када са знатижељом слушају туђе приче, не уступају место туђим приповедачким гласовима" (Љуштановић 2012: 142). 
konkordanciju s engleskim prevodom i kritičkim izdanjem sanskrtskog teksta po pevanjima, napisao napomenu i beleške Miroslav Ježić, pogovor Dušan Pajin, Novi Sad: Svetovi.

СМ (2001): Словенска мийолойија (ред. Светлана М. Толстој и Љубинко Раденковић), Београд: Zepter Book World.

\title{
ЛИТЕРАТУРА
}

Беновска-Събкова (1992): Милена Беновска-Събкова, Змеят в бългрския фолклор, София: Българската академия на науките.

Гура (2005): Александар Гура, Симболика живоӣиња у словенској народној йраяицији, Београд: Бримо.

Елијаде (1996): Мирча Елијаде, Воgич кроз свейске релиїије, Београд: Народна књига - Алфа.

Иванов, Топоров (1965): Вячеслав Всеволодович Иванов, Владимир Николаевич Топоров, Славянские языковые моделирующие семиотические системы, Москва: Издательство „Наука”.

Иванов, Топоров (1974): Вячеслав Всеволодович Иванов, Владимир Николаевич Топоров, Исследования в области славянских древностей, Москва: Издательство „Наука”.

Кравар (2010): Zoran Kravar, Kad je svijet bio mlad, Beograd: Službeni glasnik.

Леже (1984): Luj Leže, Slovenska mitologija, Beograd: Grafos.

Ловмјански (1996): Henrik Lovmjanski, Religija Slovena, Beograd: Slovograf.

Љуштановић (2012): Јован Љуштановић, Кюижевносӣ за gецу у оі̆леgалу кулйуре, Нови Сад: Змајеве дечје игре.

Недељковић (1990): Миле Недељковић, Гоgишњи обичаји у Срба, Београд: Вук Караџић. knjiga.

Рибаков (2015): Boris A. Ribakov, Paganstvo Starih Slovena, Novi Sad: Akademska

\author{
Драголюб Ж. Перич \\ Университет Нови-Сад \\ Философский факультет \\ Кафедра сербской литературы
}

\section{РЕМИФОЛОГИЗАЦИЯ МИФОЛОГИЧЕСКОГО ПРОШЛОГО - ЛИТЕРАТУРНАЯ ИНТЕРПРЕТАЦИЯ СЛАВЯНСКОГО ПАНТЕОНА В СБОРНИКЕ РАССКАЗОВ ДЛЯ ДЕТЕЙ ГРЯЗНАЯ ЛОШАДЬ ВЕСНИ АЛЕКСИЧ}

Резюме: В настоящеи работе рассматривается литературное моделирование фрагментов словянской мифологии в сборнике рассказов Грязная лошадь Весни Алексич. Поэтому что всеобъемлющий миф о словянских богах и их первоработах, в которому они моделируют лицо мира, как его создатели, не существует, а только 
несколько несвязанных фрагментов, очень уменьшенныйх исторических данных и свидетельств из времени принятия христианства, а также и ряд мотивов, смещенных на уровень низшей мифологии (демонологии) в словенском фольклоре, подход к этому материалу требует особой осторожности, потому что каждая последующая попытка его литературной реконструкции или предварительной трансформации сталкивается с рядом несоответствий, тёмных мест, даже произвольностей. К сожалению, Весни Алексич не оказалось сопротивляться этому проблему: от талантливого писателя для детей, в этой книге она принадлежит к нехорошому митотворцу, который, в попытке восстановить некоторые элементы мифа (божества, их атрибуты и функции) во вступительных рассказах, т.е. двенадцать тематических ядер, вокруг которых затем группироваются её рассказы (часто с ребёнком в качестве рассказчика или фокусника) теряет повествовательный поток, вводит нефункциональных персонажей и ненужные детали, только для того чтобы показать, что мир древнего прошлого Славян оказался богаче, а мифологическо-демонологическая система персонажей более всеобъемлющей.

Ключевые слова: система словянской мифологии, фольклор, мифологический прототип, рассказ, литературная трансформация, повествование, вторичный мир, ребёнок рассказчик, литература для детей. 